\title{
Environmental biotechnology for the treatment of waste effluents from biofuels production
}

\author{
Bojana Bajić, Zorana Rončević, Jovana Grahovac, Siniša Dodić, Aleksandar Jokić, Damjan Vučurović, Jelena Dodić
}

\begin{abstract}
Bioethanol, biodiesel and biogas represent very significant alternatives to fossil fuels in order to reduce carbondioxide emissions, so there is a need to develop energy efficient technologies, equipment and waste management procedures to make production profitable by reducing production costs. One way to accomplish this is to solve the problem of waste effluents by using them to obtain high-value products. All biotechnological processes are energy intensive to some extent, so saving energy becomes one of the main goals of all biotechnological processes in addition to preserving the environment and the management or reuse of waste. The availability of waste effluents from the production of biofuels, such as distillery stillage and crude glycerol, will increase over the next few years due to the growth of the biofuel industry and will provide a great possibility for the biotechnological production of high-value products.
\end{abstract}

Keywords - environmental protection, biofuels, zero emissions, biotechnology, waste management

\section{Introduction}

Limited amounts and rising prices of fossil fuels have led to an increasing need for renewable, sustainable and cheap alternative sources of energy whose use is economically viable (1). Due to this, biofuels such as bioethanol, biogas and biodiesel, have become a realistic alternative in the energy market, whose production is expected to rise substantially in the near future. In order to solve environmental problems and to approach a zero waste goal, much effort has been devoted to waste minimization and economically viable sustainable production $(2,3)$. The European Union expects an annual biofuel increase of $6.3 \%$ from 2005 to 2030. Moreover, according to the European Union's 2003/30/EC directive about biofuel use, all members should replace as much as $20 \%$ of fossil fuels with fuels from renewable raw materials by $2020(4,5)$.

Biofuels are usually classified as first, second, third and fourth generation biofuels and represent low emission, nontoxic, safer and environmentally acceptable sources of energy. Available types of biofuels are bioethanol, renewable methanol, biodiesel, biogas, biobutanol and biohydrogen. Research on biofuel is currently ongoing worldwide for technological development to use this eco-fuel in the transport sector. Literature reported that sustainable energy development strategies typically involve three major technical changes such as lower demand for energy, efficiency improvements in energy production and replacement of fossil fuels by various sources of renewable energy $(6,7)$.

First generation biofuel production has raised concerns due to the discharge of significant amounts of generated liquid effluents (8). Taking into account the amount of waste generated by the biofuel industry and the fact that it contains a high inorganic and organic load it is clear that they are a large environmental pollutant but also a potentially valuable raw material if economically viable treatment procedures are available. Biotechnological production, which consists of using biocatalysts to convert the raw material into a high-value product, presents a possibility for sustainable development.

The aim of this paper is to consolidate data published in scientific literature in the last decades regarding the potential use of waste effluents obtained in production of biofuels. Also, current state and future perspectives of biofuel and waste effluents from biofuel production in Serbia are described. Systemization of the acquired data should provide information how these effluents can be used in biotechnological production of different, high-value products.

\section{Biotechnological production based on waste effluents from bioethanol production}

Bioethanol is one of the best fossil fuel alternatives since it is both renewable and environmentally friendly. Renewable resources for bioethanol production are sugar, starch and lignocellulose raw materials. But by-products and intermediates of sugar beet processing should not be neglected, as well as specifically intended cultures which could be planted on currently non-cultivated soils in Serbia. Average yields of agricultural crops in Vojvodina and potential bioethanol yields obtained from agricultural crops, different waste products and by-product is shown in Table I. Ethanol can be used in the food, pharmaceutical and chemical industries, as well as other industrial branches as a solvent, additive or raw material for various technological processes. It was traditionally used for the production of alcoholic beverages, however currently it is mostly produced as fuel. 
Worldwide $73 \%$ of total produced ethanol is used as fuel, $17 \%$ for alcoholic beverages and $10 \%$ for industrial applications. In Serbia, produced bioethanol is still mostly used for alcoholic beverages, for food and pharmaceutical industry (9-11).

TABLE I. AVERAGE YIELDS OF AGRICULTURAL CROPS IN VOJVODINA AND POTENTIAL BIOETHANOL YIELDS FROM AGRICULTURAL CROPS, WASTE PRODUCTS AND BY PRODUCTS FROM INDUSTRY AND AGRICULTURE (10)

\begin{tabular}{|l|c|c|}
\hline \multicolumn{1}{|c|}{ Raw material } & Yield $\left(\right.$ tons/km ${ }^{2}$ ) & Bioethanol yield (L/tons) \\
\hline Sugar beet & $3400-4500$ & 80 \\
\hline Corn & $4500-6500$ & 350 \\
\hline Wheat & $300-500$ & 370 \\
\hline Sugar cane molasses & - & $250-330$ \\
\hline Whey (sweet) & - & 20 \\
\hline Sulphite lye (larch) & - & 1 \\
\hline Wood & - & 200 \\
\hline Straw & - & 170 \\
\hline Corn Stalks & - & 160 \\
\hline
\end{tabular}

In Serbia bioethanol is not currently produced or used as a fuel or motor fuel additive. Specifically, Serbia currently produces bioethanol less than its demand for use in the food (beverage production), pharmaceutical and chemical industries, so that significant amounts of bioethanol are imported. Serbia, like other western Balkans countries interested in joining the European Union, has accepted the obligation of following EU policies and programs including those regarding the production and use of fuels from renewable energy sources (9). Today, bioethanol production, mostly located in Vojvodina, is performed in six industrial plants with total annual production of about 22,000 tons. All these plants perform production of bioethanol with maximal ethanol content of $95 \%$ by volume. Bioethanol production in Vojvodina currently reaches $70 \%$ of its projected capacity. When all bioethanol needs are added up, the total necessary bioethanol amount in Vojvodina is almost 6 times larger than current production. To reduce this misbalance, further investments into revitalizing current and building new production capacities are necessary $(11,12)$.

Bioethanol production from sugar, starch or lignocellulose raw materials produces a large amount of distillery stillage as a by-product. Stillage is by composition a watery solution of fermentation broth remains from distillation which contains large values of $\mathrm{COD}$ and $\mathrm{BOD}$, nitrogen, phosphorus, potassium, heavy metals and has a certain nutritional value. Its content is highly variable and its production and characteristics depends on the raw material used and various aspects of the ethanol production process. Based on this, stillage is usually used as livestock feed or as an alternative for mineral fertilizers. To reduce environmental pollution, stillage must be treated before being discharged into the environment, but this could be challenging and a number of studies encompassing physical, chemical and biological treatments have been conducted. Additionally, regardless of the type of raw material, stillage can be partially reused in the ethanol production process to utilize the remaining nutrients $(13,14)$.

Important step in overall bioethanol production is waste effluent management which can create a solution for technological advancement of bioethanol production as fuel from renewable energy sources. Wastewater management consists of the characterization of wastewater from bioethanol production and examination of the success of various physical, chemical and biological methods. Wastewater management would convert this process to the zero emission concept model.

The use of stillage for the production of a significant number of biological products including enzymes, chitosan, astaxanthin, lactic acid, xanthan, pullulan etc. has been studied and several scientific papers regarding this issue are summarized in Table II.

TABLE II. LIST OF DIFFERENT HIGH-VALUE PRODUCTS OBTAINED WITH BIOTECHNOLOGICAL USAGE OF STILLAGE

\begin{tabular}{|c|c|c|}
\hline Product & Description & Reference \\
\hline $\begin{array}{l}\text { Bacterial } \\
\text { cellulose }\end{array}$ & $\begin{array}{l}\text { Grain-based thin stillage } \\
\text { Gluconacetobacter xylinus }\end{array}$ & 15 \\
\hline Acid protease & $\begin{array}{l}\text { Rice-spirit thin stillage } \\
\text { Aspergillus niger }\end{array}$ & 16 \\
\hline Lactic acid & $\begin{array}{c}\text { Triticale stillage } \\
\text { Lactobacillus fermentum PL-1 }\end{array}$ & 17 \\
\hline Ethanol & $\begin{array}{c}\text { Wheat starch stillage } \\
\text { Zymomonas mobilis ZM4(pZB5) }\end{array}$ & 18 \\
\hline $\begin{array}{l}\text { Single cell } \\
\text { protein }\end{array}$ & $\begin{array}{c}\text { Sugar beet stillage } \\
\text { Hansenula sp }\end{array}$ & 19 \\
\hline Xylanase & $\begin{array}{l}\text { Anaerobically treated stillage } \\
\text { Burkholderia sp. }\end{array}$ & 20 \\
\hline Chitosan & $\begin{array}{c}\text { Barley-buckwheat-shochu stillage } \\
\text { Absidia atrospora IFO } 9471 \text {, } \\
\text { Gongronella butleri IFO } 8080 \text { and } \\
\text { G. butleri IFO } 8081\end{array}$ & 21 \\
\hline $\begin{array}{l}\text { poly } \beta \text { - } \\
\text { hydroxybutyrate }\end{array}$ & $\begin{array}{c}\text { Rice grain and jowar grain stillage } \\
\text { Biomass was in the form of activated } \\
\text { sludge }\end{array}$ & 22 \\
\hline Astaxanthin & $\begin{array}{c}\text { Corn stillage } \\
\text { Phaffia rhodozyma }\end{array}$ & 23 \\
\hline Xanthan & $\begin{array}{c}\text { Corn stillage } \\
\text { Xanthomonas campestris ATCC } 13951\end{array}$ & 24 \\
\hline Pullulan & $\begin{array}{c}\text { Corn stillage } \\
\text { Aureobasidium pullulans } \mathrm{RP}-1\end{array}$ & 25 \\
\hline
\end{tabular}

Using certain technological solutions it is possible to produce biofuels in a closed cycle, thereby reducing the quantity of waste to a minimum. Distillation stillage can be used for fattening cattle and cattle excrement can produce biogas and manure as fertilizer. Combustion of lignocelullose residual waste from the production of basic raw materials starch or biogas can provide sufficient energy for the production of bioethanol. Ash from the burned biomass can be used as a replacement of mineral fertilizer due to its high mineral content. Small farms in Vojvodina would find such a closed cycle economically viable. Fig. 1 shows a schematic representation of such a process $(10,26)$. 
Proc. of the Second Intl. Conf. on Advances in Bio-Informatics and Environmental Engineering - ICABEE 2015 Copyright $($ Institute of Research Engineers and Doctors, USA .All rights reserved.

ISBN: 978-1-63248-043-9 doi: 10.15224/ 978-1-63248-043-9-33

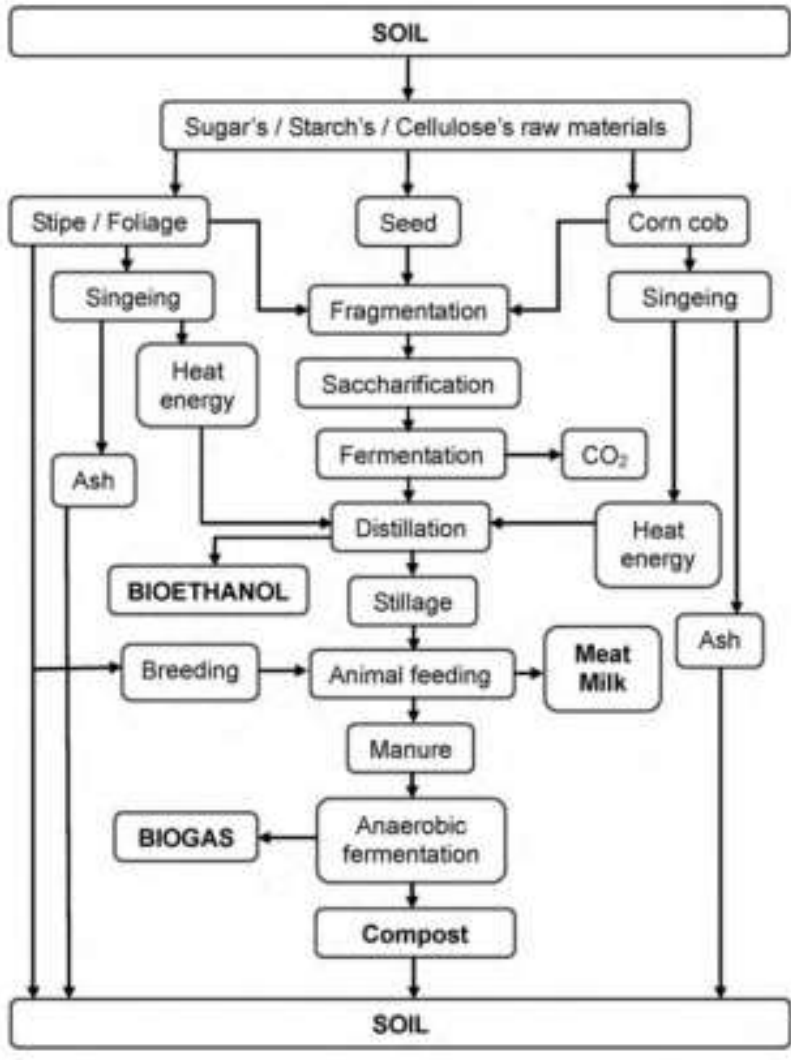

Figure 1. Cleaner biofuels production

Cost-effective process design for ethanol production as fuel consists of the selection of the most appropriate feedstocks, and selecting and defining an optimal process configuration which would ensure that the conversion of raw material into product meets the necessary specifications. Additionally, it is necessary to address the issue of management and reuse of generated waste.

\section{Application of biodiesel waste effluents as raw material for biotechnological production}

Biodiesel is a renewable and biodegradable fuel and is produced from various oils and fats by trans-esterification with ethanol or methanol. Biodiesel is produced from pure vegetable oil that is extracted mainly from the oilseeds of several Brassicaceae species (84\%), sunflower (13\%), soybean $(1 \%)$, palm $(1 \%)$, and other plant sources $(1 \%)$. Oil extraction, which can be carried out by solvent, cold pressing or a combination of both, provides oilless seed meals and/or cakes as co-products. In addition, the oil trans-esterification process also produces abundant crude glycerin as an important by-product (27). Biodiesel is biodegradable and nontoxic and significantly reduces toxic and other emissions when burned as fuel. About 10 tons of glycerol is produced for every 100 tons of biodiesel. Hence, a worldwide production of 13 million tons/year of biodiesel has also produced 1.3 million tons/year of glycerol. Recovery and use of this byproduct can significantly add value to the biodiesel production process (8).

Biodiesel production has a relatively long tradition is Serbia but is at this moment on a minimal level and only produced by small local facilities. Existing and projected capacities for biodiesel production in Serbia are more than sufficient for producing amounts of biodiesel for adding 2-7\% of biodiesel into fossil fuels. The potential area for growing oilseeds intended for biodiesel production in Serbia is approximately 350.000 ha and it could supply 212.800 to 250.600 tons of biodiesel but this represents only a theoretical potential of biodiesel production in Serbia, while the real potential is significantly lower (28).

Based on various scientific papers published in current literature it can be observed that biotechnological production using biodiesel waste product - glycerol is possible and large number of different high-value products can be obtained (Table III).

TABLE III. LIST OF DIFFERENT HIGH-VALUE PRODUCTS OBTAINED WITH BIOTECHNOLOGICAL USAGE OF GLYCEROL

\begin{tabular}{|l|c|c|}
\hline \multicolumn{1}{|c|}{ Product } & Description & Reference \\
\hline $\begin{array}{l}\text { 1,3- } \\
\text { Dihydroxyacetone }\end{array}$ & Schizochytrium limacinum & 29 \\
\hline 1,3-Propanediol & $\begin{array}{c}\text { Clostridium butyricum VPI 3266 } \\
\text { Clostridium acetobutylicum } \\
\text { DG1(pSPD5) }\end{array}$ & 30 \\
\hline Biofungicides & Streptomyces hygroscopicus & 31 \\
\hline Biofungicides & Streptomyces sp & 32 \\
\hline Citric acid & Yarrowia lipolytica NCIM 3589 & 33 \\
\hline Biobactericides & Bacillus subtilis ATCC 6633 & 34 \\
\hline Xanthan & $\begin{array}{c}\text { Xanthomonas campestris ATCC } \\
13951\end{array}$ & 35 \\
\hline Biosurfactants & $\begin{array}{c}\text { Pseudomonas aeruginosa GS9-119 } \\
\text { Pseudomonas aeruginosa } \text { DS10- } \\
129\end{array}$ & 36 \\
\hline Antibiotics & Streptomyces hygroscopicus CH-7 & 37 \\
\hline
\end{tabular}

\section{Iv. Biotechnological production of biogas using waste effluents}

Biogas typically refers to a mixture of different gases (methane, carbon-dioxide, air, ammonia, carbon-monoxide, hydrogen, sulfur gases, nitrogen, and oxygen) produced by the breakdown of organic matter in the absence of oxygen. Biogas is a type of renewable energy sources and is most often classified as a gaseous biomass. It is renewable energy source and can be used for electricity production, space, water and process heating (8). 
Serbia's potential for biogas production is estimated based on potential usage of energy crops and animal waste, such as cattle and pig manure. Table IV shows a summary of potential biogas productions and predictions for 2020. The increase in animal production on larger farms could lead to increased biogas production in the following years/decades. This increase would be realized through the merger of individual producers and small farms, as well as aiming to fulfill technology requirements by transferring capacity from small to large farms. However, biogas production from energy crops is not expected to significantly increase, since food production would be affected (38).

TABLE IV. SUMMARIZED POTENTIALS FOR BIOGAS PRODUCTION IN SERBIA

\begin{tabular}{|c|c|c|}
\hline \multirow{4}{*}{ Product } & Feedstock & $\begin{array}{c}\text { Potential biogas } \\
\text { production, } \\
\text { (mil Nm3/a) }\end{array}$ \\
\hline \multirow{4}{*}{\begin{tabular}{c} 
Anual production \\
\cline { 2 - 3 }
\end{tabular}} & Manure & 82.0 \\
\cline { 2 - 3 } & Energy crops & 33.1 \\
\hline \multirow{3}{*}{$\begin{array}{c}\text { Forecast for } \\
2020 .\end{array}$} & Sum & 115.1 \\
\cline { 2 - 3 } & Manure & 98.4 \\
\cline { 2 - 3 } & Energy crops & 33.1 \\
\hline
\end{tabular}

Additionally, since biogas is mostly produced from various waste, liquid effluents from biofuel production can be used as raw materials for its production, as shown on Figure 1. This would produce biogas whose solid waste is used as fertilizer, in addition to treating liquid effluents from bioethanol and biodiesel production.

\section{v. Conclusion}

Application of biotechnology in various fields, such as industry, agriculture and waste management is very important considering its economic and environmental benefits, since production is less expensive and product quality is increased. Increasing industrialization is a response to increasing demands of the consumer public exploits resources on the large scale and generates large amounts of wastes in addition to desired products. Natural renewable sources of raw materials can satisfy increasing needs up to an extent and are still available in necessary amounts as energy sources. The availability of waste effluents is expected to increase in the following years due to tremendous growth in the production of biofuels worldwide. Enhanced treatment, recycling of liquid streams and utilization of energy efficient waste management technologies represent realistic possibilities for improving technical, economic and environmental aspects of biofuel waste management.

The emission of large amounts of effluents into the environment is a modern problem, and with the present trend of increasing the qualitative and quantitative load it will certainly remain the problem in the future. There are numerous solutions offered to deal with aforementioned problems but only a comprehensive and meaningful approach with a clear economic gain could be sustained. Waste management in biotechnological processes not only reduces the negative emissions into the environment, but also produces significant amounts of high-value products, such as enzymes, organic acids, biopolymers, biopesticides etc. Using biotechnological processes in the production of these bio-chemicals is very important since has significant benefits.

\section{Acknowledgment}

The authors gratefully acknowledge the support of the Ministry of Education, Science and Technological development, Republic of Serbia, project number: TR-31002.

\section{References}

[1] G. Najafpour, H. Younesi and I.K.S. Ku, "Ethanol fermentation in an immobilized cell reactor using Saccharomyces cerevisiae," Bioresour Technol., vol. 92, pp. 251-260, 2004.

[2] B. Šantek, G. Gwehenberger, M. Ivančić-Šantek, M. Narodoslawsky and P. Horvat, "Evaluation of energy demand and the sustainability of different bioethanol production processes from sugar beet," Resour Conserv Recy., vol. 54, pp. 872-877, 2011.

[3] E. Alkaya and G. Demirer, "Anaerobic acidification of sugar-beet processing wastes: Effect of operational parameters," Biomass bioenerg, vol. 35, pp. 32-39, 2011.

[4] F. Coppola, S. Bastianoni and H. Østergård, "Sustainability of bioethanol production from wheat with recycled residues as evaluated by energy assessment," Biomass Bioenerg, vol. 33, pp. 1626-1642, 2009.

[5] X. Wu, S. Staggenborg, J. Propheter, W. Rooney, J. Yu and D. Wang, "Features of sweet sorghum juice and their performance in ethanol fermentation," Ind Crops Prod, vol. 31, pp. 164-170, 2010.

[6] A. K. Azad, M. G. Rasul, M. M. K. Khan, S. C. Sharma and M. A. Hazrat, "Prospect of biofuels as an alternative transport fuel in Australia," Renew Sust Energ Rev., vol. 43, pp. 331-335, 2015.

[7] A. Demirbas, "Competitive liquid biofuels from biomass," Appl Energ., vol. 88, pp. 17-28, 2011.

[8] R. Gupta and A. Demirbas, Gasoline, Diesel, and Ethanol Biofuels from Grasses and Plants. New York: Cambrige University Press, 2010.

[9] Z. Zavargo, S. Popov, S. Dodić, R. Razmovski, R. Tomanović, J. Dodić and A. Jokić, Possibilities for the development of bioethanol production and application in the Autonomous Province of Vojvodina (in Serbian), Novi Sad, 2008.

[10] S. Dodić, S. Popov, J. Dodić, J. Ranković and Z. Zavargo, "Potential development of bioethanol production in Vojvodina," Renew Sust Energ Rev., vol. 13, pp. 2722-2727, 2009.

[11] J. Grahovac, J. Dodić, S. Popov, S. Dodić, D. Vučurović, I. Tadijan and A. Jokić, "Bioethanol production technologies: current situation and perspectives in Vojvodina," Tractors and p/m., vol. 16, pp. 121-128, 2011.

[12] S. Dodić, S. Popov, J. Dodić, J. Ranković and Z. Zavargo, "Potential contribution of bioethanol fuel to the transport sector of Vojvodina," Renew Sust Energ Rev., vol. 13, pp. 2197-2200, 2009.

[13] P. Singh, T. Robinson and D. Singh, "Treatment of industrial effluentsdistillery effluent", in Concise Encyclopedia of Bioresource Technology, A. Pandey, Eds. New York: Food Products Press, 2004, pp. 135-141.

[14] S. Mohana, B. Acharya and D. Madamwar, "Distillery spent wash: Treatment technologies and potential applications," J. Hazard. Mater., vol. 163, pp. 12-25, 2009.

[15] J.M. Wu and R.H.Liu, "Cost-effective production of bacterial cellulose in static cultures using distillery wastewater," J. Biosci. Bioeng., vol. 115, pp. 284-290, 2013. 
[16] F.C. Yang and I.H. Lin, "Production of acid protease using thin stillage from a rice-spirit distillery by Aspergillus niger. Enzyme Microb Tech., vol. 23, pp. 397-402, 1998.

[17] M. Marković, S. Markov, O. Grujić, Lj. Mojović, S.Kocić-Tanackov, M. Vukašinović and J.Pejin, "Microwave as a pre-treatment of triticale for bioethanol fermentation and utilization of the stillage for lactic acid fermentation," Biochem Eng J., vol. 85, pp. 132-138, 2014.

[18] L. Davis, Y. J. .Jeon, C. Svenson, P. J. Rogers, P. Jearce and P. Peiris, "Evaluation of wheat stillage for ethanol production by recombinant Zymomonas mobilis," Biomass Bioenerg., vol. 29, pp. 49-59, 2005.

[19] S. A. Shojaosadati, R. Khalilzadeh, A. Jalilzadeha and H. R. Sanaei. Bioconversion of molasses stillage to protein as an economic treatment of this effluent," Resour Conserv Recy., vol. 27, pp. 125-138, 1999.

[20] S. Mohana, A. Shah, J. Divecha and D. Madamwar, "Xylanase production by Burkholderia sp. DMAX strain under SSF using distillery spent wash," Biores Technol., vol. 99, pp. 7553-7564, 2008.

[21] H. Yokoi, T. Aratake, S. Nishio, J. Hirose, S. Hayashi and Y. Takasaki, "Chitosan production from shochu distillery wastewater by funguses," J. Ferment. Bioeng., vol. 85, pp. 246-249, 1998.

[22] A. A. Khardenavis, S. M. Kumar, S. N. Mudliar and T. Chakrabarti, "Biotechnology conversion of agro-industrial wastewaters into biodegradable plastics, poly $\beta$-hydroxybutyrate," Bioresour. Technol., vol. 98, pp. 3579-3584, 2007.

[23] T.D. Leathers, "Bioconversions of maize residues to value-added coproducts using yeast-like fungi," FEMS Yeast Res., vol. 3, pp. 133140, 2003.

[24] J. Dodić, J. Grahovac, A. Jokić, B. Bajić, S. Dodić, D. Vučurović and S. Popov, "Biological treatment of different food industrial wastewater by Xanthomonas campestris," Proceedings of IcoSTAF 2012, pp. 41-46, Szeged, June 2012.

[25] T.P. West and B. Strohfus, "Pullulan production by Aureobasidium pullulans grown on ethanol stillage as a nitrogen source," Microbios., vol. 88, pp. 7-18, 1996.

[26] S. Dodić, D. Vučurović, S. Popov, J. Dodić and J. Ranković, "Cleaner bioprocesses for promoting zero-emission biofuels production in Vojvodina," Renew Sust Energ Rev., vol. 14, pp. 3242-3246, 2010.

[27] A. Demirbas, "Biomass resources for energy and chemical industry," Energy Educ. Sci. Technol., vol. 5, pp. 21-45, 2000.

[28] M. Tešić, F. Kiš and V. Janković, "The possibility of production and use of biodiesel in Serbia (In Serbian), Belgrade, Jeffersonian institute, 2010.

[29] D.J. Pyle, R. A. Garcia, and Z. Y. Wen, "Producing docosahexaenoic acid (DHA)-rich algae from biodiesel- derived crude glycerol: effects of impurities on DHA production and algal biomass composition," J. Agric. Food Chem., vol. 56, pp. 3933-3939, 2008.

[30] M. González-Pajuelo, I. Meynial-Salles, F. Mendes, P. Soucaille and I. Vasconcelos, "Microbial conversion of glycerol to 1,3-propanediol: physiological comparison of a natural producer, Clostridium butyricum VPI 3266 and an engineered strain, Clostridium acetobutylicum DG1 (pSPD5),” Appl Env Microbiol., vol. 72, pp. 96-101, 2006.

[31] J. Grahovac, M. Grahovac, J. Dodić, B. Bajić and J. Balaž, "Optimization of cultivation medium for enhanced production of antifungal metabolites by Streptomyces hygroscopicus," Crop Prot., vol. 65, pp. 143-152, 2014.

[32] M. Grahovac, J. Grahovac, I. Tadijan, J. Dodić and J. Balaž, "Possibility of biofungicide production from waste glycerol, Proceedings of 2 nd International Conference: WASTES: Solutions, Treatments and Opportunities, pp 311-316, Braga, September, 2013.

[33] S. B. Imandi, V. V. R. Bandaru, S. R. Somalanka and H. R. Garapati, "Optimization of medium constituents for the production of citric acid from byproduct glycerol using Doehlert experimental design," Enzyme Microb Technol., vol. 40, pp. 1367-1372, 2007.

[34] Z. Rončević, J. Grahovac, D. Vučurović, S. Dodić, B. Bajić, I. Tadijan and J. Dodić, "Optimization of medium composition for the production of compounds effective against Xanthomonas campestris by Bacillus subtilis," Acta Periodica Technologica, vol. 45, pp. 247-258, 2014.
[35] Z. Rončević, B. Bajić, J. Grahovac, S. Dodić and J. Dodić, "Effect of the initial glycerol concentration in the medium on the xanthan biosynthesis, Acta Periodica Technologica, vol. 45, pp. 239-246, 2014

[36] K. S. M. Rahman, T. J. Rahman, S. McClean, R. Marchant and I. M. Bannat, "Rhamnolipid biosurfactant production by strains of Pseudomonas aeruginosa using low-cost raw materials," Biotechnol Prog., vol. 18, pp. 1277-1281, 2002.

[37] S.B. Ilić, S.S. Konstantinović, G.Đ. Gojgić Cvijović, D.S. Savić and V.B. Veljković, "The impact of glycerol and some carbohydrates on antibiotic production by Streptomyces hygroscopicus CH-7," Med Chem Res., vol. 22, pp. 934-937, 2013.

[38] Dj. Djatkov, "Potentials, practice and prospects of energy utilization of Biomass in serbia: gaseous biomass-biogas," Belgrade, Jeffersonian institute. 